\title{
THE ROLE OF EMPLOYMENT OF PEOPLE WITH INTELLECTUAL DISORDERS
}

\author{
Tetyana Husieva \\ Graduate Student at the Faculty of Special and Inclusive Education, \\ Sumy State Pedagogical University named after A. S. Makarenko; \\ Director of Rehabilitation Institution of Mixed Type (Comprehensive Rehabilitation) \\ for People with Disabilities due to Intellectual Disabilities, \\ Center "Assistanc" of the Public Organization "Felicitas", Ukraine \\ e-mail: utaa1970@gmail.com,orcid.org/0000-0003-3178-1631
}

\section{Summary}

The article provides a theoretical analysis of the role of work in the correction of people with disabilities due to intellectual disabilities. Different types of work in special institutions are outlined. The role of work in the education and development of people with disabilities due to intellectual disabilities is now particularly important due to the difficulties in preparing them for practice. In Ukraine, state and public systems of educational institutions and establishments have been created and are constantly developing, in order to cover all people with disabilities. An integral part of this system are special institutions where people with disabilities who have certain deviations of physical or mental development can study, get educated, prepare for independent life and socially useful work.

People with disabilities should be oriented about the role they play in the work force of the society; in that they should provide useful and affordable work. This is done in order to prepare themselves for socially useful activities, they must see the main goal to be pursued in the learning process.

In the system of pedagogical measures to influence the psyche of a person with a disability due to intellectual disabilities work is one of the most important means of correcting intellectual disabilities. The corrective value of employment for people with disabilities due to intellectual disabilities is that work greatly contributes to the education of positive personality traits. It is known that people with intellectual disabilities make poor use of work skills in new situations. Work contributes to the application of knowledge and skills acquired during training in practical activities outside the institution.

Keywords: education, upbringing, work, development, special institutions, people with disabilities.

DOI https://doi.org/10.23856/4304

\section{Introduction}

The role of work in the correction of people with disabilities due to intellectual disabilities is considered at all stages of their development and is quite relevant.

In the works of V. Bondar, L. Vavina, O. Gavrilov, I. Dmitrieva, I. Yeremenko, M. Kozlenko, N. Kolominsky, M. Matveeva, G. Mersiyanova, S. Mironova, T. Sak, V. Sinyov, N. Stadnenko, M. Suprun, K. Turchynska, O. Khokhlina, D. Shulzhenko and others. Attention is focused on the problems associated with the use of correctional training and education of 
people with disabilities due to intellectual disabilities. The researches done in this problem field of such scientists and practitioners deserve special attention: L. Wenger, G. Vygodska, O. Kataeva, E. Strebeleva, M. Sheremet and others. They emphasized the impact of early intervention and the development of the intellectual component on the further education of children with special needs in special institutions (Mironova, 2015).

Theoretical analysis of research by Soviet authors (O. Graborov, G. Dulnev, M. Kuzmytska, I. Yeremenko, L. Zankova, etc.) showed that the problem of teaching people with disabilities manual and professional work is quite relevant in terms of correctional work with this category of people.

Ukrainian researchers, such as V. Bondar, V. Zasenko, V. Sinyov and other authors, emphasized the provision of equal rights of all children to quality education, taking into account their typological and individual characteristics through the development of various forms of education - inclusive and special institutions.

Immersed in the problem of social rehabilitation of people with disabilities, is considered occupational therapy, which L. Vakulenko described rather narrowly, as a method of helping people with physical and mental disabilities, to teach them to behave better, and for people with intellectual disabilities - to overcome emotional problems. By involving them in specially organized activities (Vakulenko, 2018).

The issue of teaching people with disabilities due to intellectual disabilities has been studied by a number of researchers (I. Akimenko, A. Graborov, I. Daniushevsky, G. Dulnev, M. Kuzmytska, M. Ryabtsev, and V. Tarasov).

However, the theoretical analysis of the problem of the role of work in the correction of people with disabilities due to intellectual disabilities showed its lack of development, which actualizes research in this area. Therefore, the aim of the work is a theoretical analysis of the role of work in the rehabilitation of intellectually disabled people and the development of recommendations for the organization of work aimed at correcting the disabilities of people with disabilities due to intellectual disabilities.

The study sets the following objectives:

1. Analysis of psychological and pedagogical literature on the research problem.

2. Determining the role of work in the correction of defects in people with disabilities due to intellectual disabilities.

3. Identifying the effectiveness of organized labor in the rehabilitation of intellectually disabled people.

4. Development of recommendations for the organization of work aimed at correcting the disabilities of people with disabilities due to intellectual disabilities.

The following methods were used in the study:

- Analysis of scientific and methodological literature on the research problem.

- Observations.

\section{Correctional work with people with disabilities in special institutions}

Domestic institutions of auxiliary schools and rehabilitation institutions pay great attention to labor training in the development of people with disabilities due to intellectual disabilities. This is reflected in the curricula and programs of these institutions. By teaching people with disabilities due to intellectual disabilities, the teacher corrects the shortcomings of work and forms their relationships in the team. It is obvious that labor education is associated with physical, moral, aesthetic and environmental education. Systematically performed work allows 
them to develop a sense of duty, responsibility for the task and such personality traits as perseverance, honesty, truthfulness (Mersiyanova, 2012).

Occupational therapy allows people with disabilities to feel included in processes which has a beneficial effect on the whole body. They develop the necessary skills: personal hygiene, the habit of monitoring the cleanliness of the room, which creates the conditions for a healthy lifestyle. The inclusion of people with disabilities due to intellectual disabilities in various types of work also allows them to understand the beauty, to enjoy the result.

In the process of studying in special institutions, the teacher deals with a certain category of people with disabilities due to intellectual disabilities, which are significantly different from their peers in terms of mental activity. Knowledge of these features is necessary for effective work, to understand the reasons for the successes and failures of teaching and education, to find adequate ways and methods of pedagogical influence.

S. Mironova noted that people with disabilities due to intellectual disabilities are deficient in all levels of mental activity. They are complicated by the solution of the simplest practical problems, such as combining a 2-3-part image of a familiar object, choosing a geometric shape, identical in shape and size to the corresponding one available on the surface of the recess ("mailbox") and they perform similar tasks with a large number of errors, after many attempts, and the same errors are repeated many times. I must say that the implementation of practical actions in itself is complicated, because the motor and sensory cognition of people with disabilities due to intellectual disabilities is incomplete (Mironova, 2004).

Characterizing the thinking of people with disabilities due to intellectual disabilities, we should emphasize the stereotypes, rigidity of this process. That is why the application of existing knowledge in new conditions causes them difficulties and often leads to incorrect task performance.

Specially organized training and education are essential for the promotion of general development, for the acquisition of knowledge, skills and abilities in this category of people. Special training aimed at the development involves, first of all, the formation of their higher mental processes, especially thinking, this important area of correctional work is theoretically justified by the fact that defects in the process of thinking are particularly sharp and in turn, inhibit and complicate knowledge of the world around us. However, it has been proven that the thinking of people with disabilities due to intellectual disabilities is undoubtedly evolving. In the process of correction of intellectual activity there is a development in general and this creates a real basis for social and labor adaptation of people with disabilities.

Thus, the specific features of the psyche of people with disabilities due to intellectual disabilities leads to the need to take into account these features in the training and education in the correctional work of teachers of special institutions and rehabilitation institutions.

\section{Psychological preparation of people with disabilities for work}

Special institutions are designed to pay great attention to psychologically prepare these people for work and set themselves for a number of tasks.

One of such tasks is to correct the shortcomings of the general mental development, each task is closely related to each other, no task is less important - in order to ensure conscious and strong assimilation of information by clients in the workplace information, skills and abilities (Sinyov, 2008).

In the process of labor training, clients form the right attitude towards the messages of the teacher and the development of skills. Performing the necessary processes of measurement, 
weighing, determining in the process of work the shape, size, volume, color and other qualities of the material with which the client operates, he is convinced that the knowledge reported by the teacher is important for him (Kutishenko, 2010).

People with disabilities due to intellectual disabilities are known to be taught with great difficulty. They often have to go through failures, to make sure they are not always able to properly perform the tasks of a teacher. All this shapes the clients' attitude towards learning as an activity that is not very accessible to them. It should also be born in mind that the importance of education, its benefits and significance for society can be fully understood only from the standpoint of the future, in terms of the role it plays in the social and labor activities of the client after graduation. Such awareness is given to people with disabilities due to intellectual disabilities with great difficulty.

Quite different results are obtained when combining training with work. For work to be successful, a person with a disability must master the ways and purposeful actions needed to achieve the goal. The activity itself should stimulate and support the client's activity. This means that work is impossible without volitional and cognitive processes. A sign of work the presence of a conscious goal (Krushelnytska, 2000) and the results of the work can be felt directly. The work itself and the resulting product (products) - cause people with disabilities due to intellectual disabilities lively interest and encourage them to be active and purposeful.

\section{Types of work}

In special institutions, different types of work are used to work with clients. Work can take place in the process of learning activities in the classroom, and in the free time of the client.

Labor activity can be divided into four main types:

1. Self-service.

2. Household work.

3. Manual labor.

4. Socially useful work.

Self-care is a constant concern for the cleanliness of the body, for order in clothes, readiness to do everything necessary for this and to do without external requirements, out of internal need, to follow hygienic rules. This attitude of clients to self-service work can be achieved only through painstaking systematic work of the teaching staff and family. In self-service, customers always have a specific goal, the achievement of which is clear and vital for them. By caring for oneself, a person with disability shows some physical and mental effort. People with intellectual disabilities, especially those with complex defects, need to be taught the simplest but much-needed self-care skills. Hygienic culture is as important for a person as the ability to speak, write, and read. Self-care gives a person a wonderful feeling of purity, health: every cell of the body begins to live in an optimal mode, bringing joy to each person. It is through self-care that a person for the first time establishes a known relationship with others realizes his responsibilities to them, seeks to be useful, not to burden others, to manage on their own (Mersiyanova, 2012).

Self-service training takes place in the form of joint activities of the teacher and clients, with the leading role belongs to the teacher. Such conditions are created for training, which give each client the opportunity to work at an affordable pace, showing possible independence. The educational material is variable and is selected by the teacher independently depending on the level of development of each person with a disability due to intellectual disabilities. In the learning process, the teacher can use different forms of organization of the educational process: 
classes involving different types of activities: game (role-playing, didactic, theatrical, moving game), elementary labor, constructive work on the subject). The success of teaching children with moderate and severe mental disability from people with intellectual disabilities due to intellectual disabilities depends on the variety of methods and techniques used in the classroom. Their choice depends on the content of the lesson, the peculiarities of the psychophysical development of the clients.

In the process of teaching people with disabilities due to intellectual disabilities self-care skills, it is advisable to use the following methods and techniques:

1. Detailed display and explanation of each movement in their sequence. Crucial to this is the active behavior of the client, ire his practical participation in this action. algorithm.

2. Keeping the same method unchanged, the same sequence of actions to develop the

3. Repeated repetition of the same actions in a certain sequence.

4. Gradual transition from demonstration to verbal explanations. They help to consolidate skills, develop precise movements, and provide an opportunity to act in accordance with each word of the teacher.

When developing washing skills, it is important not to limit the independence of customers. As some master the skills, the teacher engages them in helping peers. Cultural and hygienic skills are formed in the process of nutrition: the ability to eat independently and neatly, to hold a spoon correctly, etc.

People with disabilities are more helpless in dressing and undressing due to intellectual disabilities. When learning this, it is necessary to follow a certain sequence: what to take off or put on first, where to put clothes. Teaching the client, the teacher at the same time encourages him to actively participate in the process of dressing. The clients listen to what the teacher is saying and gradually begin to do the same. When they become more independent, the teacher offers them to help each other unbutton buttons, lace up shoes, put shoes in a bag.

In household chores, clients take care of furniture, houseplants, perform simple cleaning work, are able to recognize types of clothing and footwear correctly name and classify them. The main purpose of the lesson "Household work" is to master the simplest practical skills of housekeeping. Thus, through classes on household work, the involvement of people with disabilities is formed due to intellectual disabilities to socially useful work available to them and the acquisition of social experience.

Manual work develops design skills, plays an important role in the mental and aesthetic education of people with disabilities due to intellectual disabilities, the development of their creative and technical abilities.

Manual labor is the most important type of work in special institutions; it is aimed at training clients to work with different materials. In addition, manual labor has a corrective effect on the mental development of people with disabilities. For example, special attention in handicraft classes is paid to educating clients in the habit of thinking about the task, rather than immediately performing it. In this regard, it is difficult to overestimate the value of application work, during which it is necessary to pre-determine the place of gluing of individual parts of the application, as well as to follow the sequence of gluing. In the process of such classes, clients develop skills of organization, the ability to act according to a pre-arranged plan.

Application works are used to develop spatial representation, as people with disabilities due to intellectual disabilities experience significant difficulties in the correct placement of parts relative to each other. Similarly, in the independent use of the corresponding words: above, in the middle, around, above on the right, on the left, and so on. 
Even more importance is attached to socially useful work. It should be noted that to increase the interest and activity of people with disabilities due to intellectual disabilities in the learning process, it is necessary that they realize the importance and usefulness of what they do, understand that the results of their activities have known practical and social significance. This awareness is facilitated by combining learning with community service.

People with disabilities due to intellectual disabilities need to be taught to put into practice the knowledge acquired in institutions. Initially, in work lessons, clients work with paper and cardboard, textiles, modeling, working with wood. And in the future, gaining some experience, engaged mainly in one of the types of work - sewing, carpentry, cardboard and binding, etc. including self-service work.

\section{Organization of classes in leisure time}

All the research and extensive practice of special institutions help to solve many issues of training intellectually disabled people to live in the society and to work in the conditions of production, their social and labor adaptation. One third of the study time is devoted to labor training in special institutions. However, this fact does not preclude the expediency of organizing classes in the client's free time.

Extracurricular activities are one of the forms of work with people with disabilities due to intellectual disabilities, which greatly contributes to the education of positive personality traits. It is known that people with disabilities due to intellectual disabilities make poor use of work skills in a new situation. Extracurricular activities promote the application of knowledge and skills acquired during training in practical activities outside the institution.

The content of extracurricular activities should help solve the main tasks facing labor training in special institutions: labor training should be socially significant. That is, it should practically prepare customers for inclusion in the productive work of the society; labor training should be used to correct the psychophysical deficiencies of people with disabilities due to intellectual disabilities; labor activity should contribute to the formation of moral qualities of the client's personality. Extracurricular activities are a natural addition to the types of work performed under the labor training program (Mironova, 2004).

In extracurricular activities, clients deal with the same materials and tools as in occupational classes. However, the nature of classes and types of products differ significantly. Naturally, extracurricular activities should not duplicate the types of work that clients study in the labor training program. Types of work should be selected in such a way that the knowledge, skills and abilities acquired in the employment classes and in the general education cycle, can be improved and consolidated in extracurricular activities.

For example, if the clients are engaged in modeling in labor lessons, it is useful to organize work with paper or natural materials in extracurricular activities.

It should be born in mind that the instability of the cognitive interests of people with disabilities due to intellectual disabilities and fatigue from monotonous activities require at some point to change the types of work. Therefore, the content of extracurricular activities should include several different types of work. It is also necessary to take into account the sensory experience of clients and to include in the content of training elements of artistic activity, game moments, as well as observations in nature. In addition to the fact that extracurricular activities are closely related to lessons of labor training and general education subjects, they also have connections with other types and forms of amateur activities of clients. These include, for example, puppet and shadow theaters which involves 
the manufacture of products from wood, metal, paper, papier-mâché, making decorations, sewing costumes, etc.

Forms of extracurricular activities, such as excursions to enterprises, agricultural organizations, job interviews, and screenings of films about adult production and work, are very important for labor training and education of people with disabilities due to intellectual disabilities. Such meetings and conversations significantly expand the clients' understanding of the nature of different professions, the specifics of production and arouse interest. It is desirable to carry out such work in special institutions as often as possible. Using a variety of forms of educational work on labor training, the teaching staff of special institutions will be able to more successfully solve the tasks of preparing people with disabilities due to intellectual disabilities to participate in productive work of society, correction of psychophysical shortcomings of clients and education of their positive qualities.

\section{Recommendations for the organization of labor activity}

Recommendations for the organization of labor activities, which are aimed at correcting disorders in people with disabilities due to intellectual disabilities:

1. Use a variety of work activities. In the process of this activity it is necessary to develop the skills of independence, collectivism, etc.

2. Work should take place in conditions of curiosity, with the use of games, entertainment moments. So, during the shifts in the dining room you can hold a contest, for example, for the best table setting. You can have conversations with customers about what appliances will be needed to set the table, how best to set the table and how it can be decorated.

3. Involve clients themselves in the evaluation of their work. Teach them to express judgments about the quality of work done by their peers.

4. Work should be based on the mental capabilities of people with disabilities due to intellectual disabilities.

\section{Conclusions}

Work is a necessary condition for the formation of important personality traits. Joint work with the teacher - self-service, household, manual labor becomes important for people with disabilities due to intellectual disabilities and allows them to successfully enter into real labor relations. Improving the process of labor training is one of the main tasks in light of reforming the correctional education. After all, only in work a person can fully and comprehensively develop, reveal his/her abilities and talents and find place of their own in life.

The results of theoretical research indicate the importance of work in the correctional development of people with disabilities due to intellectual disabilities. Specific features of the psyche of people with disabilities due to intellectual disabilities lead to the need to take into account these features in education and upbringing in special institutions. This primarily applies to the use of corrective purposes for different types of work. In special institutions when working with people with disabilities due to intellectual disabilities, different types of work are used. Work can take place in the process of learning activities in the classroom, and in extracurricular activities. Such types of labor activity are used as: self-service, household work, work on care of plants and animals, manual work. With the proper use of various types of work in special institutions, the correction of the development of people with disabilities due to intellectual disabilities will effectively approach their education and training. 
The study showed that the independence of clients in work is ensured by the appropriate construction of a developmental environment, targeted assistance to the teacher in mastering the methods of work.

Thus, the results of the study indicate the need for a program of labor training, taking into account such requirements.

1. The program of labor training should be based primarily on the principle of unity of training in knowledge, skills and abilities to work with correctional work to correct their mental disabilities.

2. Learning takes effect as a developmental factor only if the goal is the client himself. True correction of mental defects can be done only by following this principle.

3. The labor training program should include more work aimed at developing creative thinking in clients. To this end, it is necessary to introduce into the program classes with readymade parts - designers, work with semi-finished products for various construction games, etc.

4. The most important thing to consider is the need to accustom clients to independence as an important quality of personality needed in human life.

\section{References}

Vakulenko L. O. (2018). Osnovy reabilitatsii, fizychnoi terapii, erhoterapii : pidruchnyk [Fundamentals of rehabilitation, physical therapy, occupational therapy: textbook]. Ternopil : Ukrmedkn.: TDMU. [in Ukrainian]

Krushelnytska Ya. V. (2000). Fiziolohiia i psykholohiia pratsi; navch. posib. [Physiology and psychology of work; textbook]. Kyiv : KNEU. [in Ukrainian]

Kutishenko V. P. (2010). Vikova ta pedahohichna psykholohiia (kurs lektsii): navch. posib. [Age and pedagogical psychology (course of lectures): textbook]. Kyiv : Tsentr uchbovoi literatury. [in Ukrainian]

Mersiianova H. M. (2012). Profesiino-trudove navchannia u spetsialnykh zahalnoosvitnikh navchalnykh zakladakh dlia rozumovo vidstalykh ditei [Vocational training in special secondary schools for mentally retarded children]. Kyiv : Pedahohichna dumka. [in Ukrainian] Myronova S. P. (2004). Psykholoho-pedahohichni osnovy korektsiinoi roboty $v$ spetsialnii shkoli [Psychological and pedagogical bases of correctional work in a special school]. Kamianets-Podilskyi : Kamianets-Podilskyi derzhavnyi universytet, informatsiino-vydavnychyi viddil. [in Ukrainian]

Myronova S. P. (2015). Korektsiina psykhopedahohika. Olihofrenopedahohika. Pidruchnyk [Correctional psychopedagogy. Oligophrenopedagogy Textbook]. Kamianets-Podilskyi: Kamianets-Podilskyi natsionalnyi universytet im. I. Ohiienka. [in Ukrainian]

Synov V. M. (2008). Psykholohiia rozumovo vidstaloi dytyny [Psychology of a mentally retarded child]. Kyiv : Znannia. [in Ukrainian] 